\title{
Profile and Susceptibility to Vaginal Yeast of Women Met on a Gynecology Outpatient Clinic
}

Kévia Katiúcia Santos Bezerra1, Maria do Carmo Andrade Duarte de Farias¹, Anne Milane Formiga Bezerra², Patrício Borges Maracajáa ${ }^{3}$, Alfredina dos Santos Araújo $^{3}$, Rosilene Agra da Silva ${ }^{3}$, Antônio Fernandes Filho', Francisco Alírio da Silva1, Cláudia Sarmento Gadelha1, Wilma Kátia Trigueiro Bezerra ${ }^{4}$, Anderson Amaro dos Santos ${ }^{5}$, Luiz Carlos de Abreu ${ }^{6}$

\section{Abstract}

Introduction: The species of the genus Candida are part of the microbiota of mucosal surfaces of the gastrointestinal tract and genital, healthy. In favorable conditions can proliferate and unleash infectious processes, such as vulvovaginal candidiasis (VVC), and even oropharyngeal and systemic infections.

Objective: Tracing the profile of women met on a gynecology outpatient clinic of a city of the remote hinterland of Paraiba and identifying the presence of possible risk factors for vaginal candidiasis.

Method: The study is of exploratory, descriptive, quantitative type, conducted at the Health Center Frei Damião, Patos-PB, having as data source a structured guide to characterizing the socioeconomic profile and possible risk factors for candidiasis in patients symptomatic and asymptomatic. A speculating gynecological examination was conducted to collect vaginal secretion, and subsequently, verify the presence of Candida by culture in Sabouraud Agar. In the data process was used the Statistical Package for the Social Sciences-SPSS, in order to provide the descriptive statistics and analytical, applying the Chi-square test $\left(X^{2}\right)$ and the Fisher Exact Test. The research was approved by the Research Ethics Committee of the Federal University of Campina Grande, CAAE 35203614.8.0000.5575.

Results: The average age of the women interviewed was of $38( \pm$ 14.045). The results showed statistical dependence between age and schooling $(p<0.001)$, age and the number of pregnancies $(p<0.001)$, the number of births $(p<0.001)$ and sexual activity $(p=0.001)$; re-
1 Academic Unit of Life Sciences, Teacher training center, Federal University of Campina Grande. Cajazeiras, Paraíba, Brazil.

2 Nurse in a Mobile Emergency Service, MSU, Sousa, PB, Brazil.

3 Federal University of Campina Grande. Graduate-degree in Agroindustrial Systems, Pombal, PB, Brazil.

4 Nurse in a Mobile Emergency Service, MSU, Paulista, PB, Brazil.

5 Student of Medicine, Academic Unit of Life Sciences, Federal University of Campina Grande. Cajazeiras, Paraíba, Brazil.

6 Scientific Writing Laboratories, Faculty of Medicine of $A B C$, Santo Andre, SP, Brazil.

\section{Contact information:}

Maria do Carmo Andrade Duarte de Farias.

Academic Unit of Life Sciences, Teacher training center, Federal University of Campina Grande.

Address: Federal University of Campina Grande. Rua Sérgio Moreira de Figueiredo, sn Bairro Casas Populares, Cajazeiras, PB CEP 58900-000.

” carmo.andrade@ufcg.edu.br 
garding the history of candidiasis $47.4 \%$ of women reported episode last year; the presence of Candida sp was verified in $46.2 \%$ of participants; regarding the risk factors there was statistical dependence $(p=0.029)$ in relation to the previous use of antibiotic, characteristic of the menstrual cycle $(p=0.002)$ and the presence of stress $(p=0.003)$; the latter, in relation to the negative culture.

Conclusion: By the fact that this infection is considered a public health problem, it becomes relevant that working professionals in this area stay updated regarding the pathogenesis of $\mathrm{VVC}$, for the appropriate handling of this infection.

\section{Keywords}

Candida; Vulvovaginitis; Microbiota; Risk factors.

\section{Introduction}

Infections caused by Candida yeasts are called candidiasis or thrush, which show a broad spectrum of clinical presentations, which, depending on the affected site, are classified as superficial, with cutaneous and mucosal involvement, even deep infections, disseminated, high gravity, like the candidemia in immunocompromised patients [1].

Candidiasis can occur as a result of disruption of the host-parasite balance, triggered by changes in tissue barrier and the indigenous microbiota and commitment natural defenses, the immune [2]. Therefore, the use of broad spectrum antibiotics makes these patients more prone to infection by these yeasts. There are such cases, suppression of the indigenous bacterial flora, allowing greater proliferation of Candida species [3-4].

Vulvovaginitis is an inflammatory process that affects the vulva, vagina and cervix, in most often causes infectious caused by bacteria, fungi, protozoa and viruses [5]. Stressing the occurrence of mycotic vulvovaginitis caused by yeast-like fungi, not always the species of the genus Candida [6].

The flora is complex and its composition varies according to a number of circumstances, such as hormonal status, number of partners, use of oral contraceptives, antibiotics, diabetes, condoms, smoking and intimate hygiene [7]. Under normal conditions, it is rich in Lactobacilli which produce hydrogen peroxide, which production is stimulated by estrogens. This mechanism makes the acidic vaginal $\mathrm{pH}$ ranging between 3.5 and 4.5 exerting a protective effect, limiting the growth of potentially harmful microorganisms. However, Candida is an exception because it thrives in acidic environment [8-9].

Yeasts are carried to the vagina through auto transmission process, from the perianal region and sourced from microbiota of the gastrointestinal tract or the exchange with the partner through sexual intercourse [10-11]. However, these organisms tend to remain housed in the vaginal mucosa and colonize only as once finding appropriate conditions to accelerate the process of multiplication and express virulence factors, culminating in the mucosa invasion and causing the Vulvovaginal Candidiasis (VVC) symptomatic [12].

The VVC is surely one of the most common diagnoses in daily gynecological practice, and became the second most frequent cause of genital infection in Brazil and in Europe, ranks first, accounting for $20-25 \%$ of vaginal discharge of an infectious nature, and lower in frequency only for bacterial vaginosis $[10,13]$. 
The multiplication of Candida in vaginal canal is favored by a number of predisposing factors. Some situations are related to the host, prior to colonization by yeast, decreased immune response observed in immunosuppressive diseases, diabetes mellitus, pregnancy and chronic corticosteroid users. Other factors may also contribute, such as the use of antibiotics, estrogen therapy, oral contraceptives [9, 14-17].

Therefore, this study was developed with the objective of tracing the profile of women attending a gynecology outpatient clinic in a city of the hinterland of Paraiba and identifying the presence of possible risk factors for vaginal candidiasis.

\section{Method}

The study is of exploratory, descriptive, quantitative type, held at the Health Center Frei Damião, in the municipality of Patos - Paraiba, in the period from July to November 2014, with the data source a structured script, covering items which allowed characterizing the socioeconomic status, health indicators and possible risk factors for candidiasis in symptomatic and asymptomatic patients. Latter there was performed gynecological speculum examination, in order to collect vaginal secretion using Swuab (Culture Swuab Transport System - CSTS). Samples of vaginal secretions were obtained from collections recommended [18-19]. Analyses were performed in the microbiology laboratory Technological Vocation Centre - TVC, Federal University of Campina Grande, campus of Pombal, Paraiba. The material was seeded onto plates containing the culture medium Sabouraud Agar (Sabouraud Dextrose Agar - DIFCO). The plates were incubated at $37^{\circ} \mathrm{C}$ for 72 hours. After this period the reading was performed and checked the growth characteristics of the colonies of Candida $s p$.

Adopting a confidence level of 95\%, $\alpha=5 \%$ and a sampling error $\alpha=5 \%$, the sample totaled 197 participants. They were included in the sample patients attending the gynecology service in the period of data collection and agreed to participate by signing the Informed Consent and Informed. In data processing we used the Statistical Package for Social Sciences (SPSS), free version 22. The numerical variables were dichotomized by the mean. Data were analyzed using descriptive statistics, with the measure of central tendency average; and the application of the chi-square test $\left(X^{2}\right)$ and the Fisher's Exact Test, when necessary, noting the values of standard deviation (SD) and Confidence Interval (CI). In compliance with Resolution 466/12, the research was approved by the Research Ethics Committee of the Federal University of Campina Grande (UFCG/CFP), CAAE 35203614.8.0000.5575 protocol.

\section{Results}

\section{Characteristics of the women interviewed}

The age of the women interviewed ranged from 14 to 79 years old, averaging 38 ( \pm 14.045); schooling ranged from 0 to 20 years, average 12 $( \pm 5.378)$; the average age at menarche and first sexual intercourse was $13( \pm 1.767)$ and $18( \pm$ 4.032) years, respectively; as the number of pregnancies and births, the average was 2 for both. However, the percentage of women who never became pregnant was $15.7 \%(n=31)$. (Data not shown in table)

Table 1 made the correlation between the age group of respondents with sociodemographic variables (education and marital status), gynecological (age at menarche and first sexual intercourse and sexual activity) and obstetric (number of pregnancies and births).

The correlation age and education, it is clear that increasing the age of the investigated, the percentage of women with less education, or in whose age ranged from 39 to 79 years, met a percentage of $68.4 \%(n=65)$ women with $0-12$ years of 
Table 1. Distribution of participants ( $n=197$ ) according to age group versus schooling, marital status and gynecological and obstetric antecedent.

\begin{tabular}{|c|c|c|c|c|c|}
\hline \multirow{3}{*}{ Socio-demographic variables } & \multicolumn{4}{|c|}{ Age } & \multirow{3}{*}{$p$} \\
\hline & \multicolumn{2}{|c|}{14 to $38(n=102)$} & \multicolumn{2}{|c|}{39 to $79(n=95)$} & \\
\hline & $n$ & $\%$ & $n$ & $\%$ & \\
\hline \multicolumn{6}{|l|}{ Schooling (years) } \\
\hline 0 to $12(n=109)$ & 44 & 43.1 & 65 & 68.4 & \multirow{2}{*}{$<0.001$} \\
\hline 13 to $20(n=88)$ & 58 & 56.9 & 30 & 31.6 & \\
\hline \multicolumn{6}{|l|}{ Fixed partner } \\
\hline Yes $(n=133)$ & 69 & 67.6 & 64 & 67.4 & \multirow{2}{*}{0.967} \\
\hline No $(n=64)$ & 33 & 32.4 & 31 & 32.6 & \\
\hline \multicolumn{6}{|l|}{ Menarche Age (years) } \\
\hline 9 to $13(n=138)$ & 75 & 73.5 & 63 & 66.3 & \multirow{2}{*}{$0.171 *$} \\
\hline 14 to $22(n=59)$ & 27 & 26.5 & 32 & 33.7 & \\
\hline \multicolumn{6}{|l|}{ Sexarche Age (years) } \\
\hline 12 to $18(n=100)$ & 52 & 51,0 & 48 & 50,5 & \multirow{2}{*}{0.949} \\
\hline 19 to $40(n=97)$ & 50 & 49,0 & 47 & 49,5 & \\
\hline \multicolumn{6}{|l|}{ Number of Pregnancies } \\
\hline 0 to $2(n=120)$ & 85 & 83.3 & 35 & 36.8 & \multirow{2}{*}{$<0.001^{\star}$} \\
\hline 3 or $+(n=77)$ & 17 & 16.7 & 60 & 63.2 & \\
\hline \multicolumn{6}{|l|}{ Number of births } \\
\hline 0 to $2(n=125)$ & 87 & 85.3 & 38 & 40.0 & \multirow{2}{*}{$<0.001^{*}$} \\
\hline 3 or $+(n=72)$ & 15 & 14.7 & 57 & 60.0 & \\
\hline \multicolumn{6}{|l|}{ Sexual activity } \\
\hline Yes $(n=172)$ & 97 & 95.1 & 75 & 78.9 & \multirow{2}{*}{$0.001^{*}$} \\
\hline No $(n=25)$ & 5 & 4.9 & 20 & 21.1 & \\
\hline \multicolumn{6}{|c|}{ Source: Research data. Patos-PB, 2014.} \\
\hline
\end{tabular}

schooling, whereas in the age group 14-38 years, this percentage was $43.1 \%(n=44)$. Thus, there was extreme statistical dependence between these variables $(p<0.001)$. (Table 1)

This survey also found up $8.6 \%(n=17)$ of illiteracy, aged $29-78$ years. However, $52.9 \%(n=9 / 17)$, were found in women over age (58 or older), and the other had aged 29-52 years. (Data not shown in tables)
By associating the age group with the marital status ( $p=0.967$ ) and age at first sexual intercourse $(p=0.949)$ was not detected statistical dependence, because the percentages between groups were roughly equivalent.

Similar to the age at first sexual intercourse, there was no statistical dependence between age and age at menarche $(p=0.171)$. However, for women of younger age, it found $73.5 \%(n=75)$ who had 
not been demonstrated dependent relationship between these variables $(p=0.545)$. (Table 2 )

On the other hand, the result of vaginal culture showed statistical dependence $(p=0.029)$ to be correlated with previous antibiotic use (there are at least a month) because the positivity percentage of $65.4 \%(n=17)$ was greater than that used in/ used such medicine. (Table 2)

Also the use of antibiotics, the result of culture revealed statistical dependence of stress history variables $(p=0.003)$ and feature of the menstrual cycle ( $p=0.002)$. However, the first prevailed $69.5 \%$ $(n=41)$ in a negative culture for women with stress history, against $52.9 \%(n=73)$ positive culture for history without stress; and second, prevailed $72.9 \%$ $(n=35)$ in a negative culture for women with absent menstrual cycle, against $51.7 \%(n=76)$ with positive culture for menstrual present, regular or irregular cycle. (Table 2)

\section{Discussion}

The results of this research on age versus schooling corroborate information released by the $\mathrm{Na}$ tional Research by Household Sampling (PNAD), that illiteracy is higher among older people. In Brazil, the absence of studies reaches 23, 9\% among those who are 60 years old or over and $9.2 \%$ in the range $40-59$ years old. And it will reduce as the age decreases: $4.6 \% 30-39,2.3 \%$ from $25-29,1.5 \%$ from $20-24$ and $1 \%$ of $15-19$ years old. This same research shows that the average number of years of study population aged 25 or older grew in all age groups. It emphasizes the increase in the number of years of education in the age group of 25 to 30 years old between 2001 and 2011, which increased from 7.4 years to 9.6 years [21].

The first sexual intercourse is considered a milestone in reproductive life and, though not found in this investigation, there has been increasingly early and has declined over the years [22].
Contrary to Table 1 findings, another study [23] showed that teenagers begin their sexual lives an average of $15.9 \pm 1.2$ years and adult reported first sexual intercourse with $17.8 \pm 1.3$ years $(p<0.05)$.

The menarche corresponds to a late event in puberty and is an important indicator of sexual maturation. But the age at menarche has a large individual variation. The trend anticipation of age at menarche is a universal phenomenon that has been observed for more than a century, and related to changes in environmental, genetic factors and variables such as ethnicity, socio-economic status and nutritional status [24-26].

So there are data in the literature that corroborate the trend of early menarche found in this study [27], in which the said menarche 3.4 months in 10 years in the population, from 12.35 years in 2001 to 12.8 years in 2010.

Regarding the age of the women and obstetric history, data corroborate those found by researchers who found that adult patients had multiple pregnancies and births [23].

Studies show that fertility in Brazil has been taking place in a sustained manner in the medium and high socioeconomic strata and recently more intensively in the strata of lower economic level [28]. The country's fertility rate, which in 1960 was 5.8 children per woman, fell to 2.3 children in 2000 and 1.9 children in 2010 . The number of children per couple is declining since the late 1960 [29].

Thus, the average number of children was lower than that called replacement rate, which is 2.1 children per woman, which is the minimum children every Brazilian should generate for that in 2040, the total population of Brazil remains stable [30].

The findings for age and sexual activity were also observed in other studies [31-32], in which most women reported decreased sexual activity after menopause, in addition, 74\% of women between 40 and 44 years old were sexually active, compared to $40 \%$ of women between 55 and 59 , in the same condition. 
It was noticed, too, that the positive culture for Candida spp percentage found in this study was superior to the findings of previous studies that observed $40.91 \%$ [20]. In addition, yeast of the genus Candida are responsible for $20-25 \%$ of genital discharge of an infectious nature, and is the second most common type of IPV, behind bacterial vaginosis [19].

About Candida recurrence, we have that 75\% of women of childbearing age had at least one episode of candidiasis lifelong and about 5\% had frequent episodes with three or more episodes per year [33].

Several polls show that depending on the age group, geographical location and socioeconomic status more than $40 \%$ of women may have one or more species of Candida as a constituent of the vaginal flora [34-35].

Therefore, various factors related to the host and the pathogen can be considered facilitating the colonization of the vaginal mucosa by Candida spp and hence the development of candidiasis. These situations relate to alter the immune response to fungus; hyperstrogenic states; use of combined oral contraceptives; pregnancy; diabetes mellitus; antibiotics; psycho-emotional factors related to stress; intimate hygiene, such as the use of inner and outer soap tampons; inappropriate self-medication, as well as factors related to virulence of the fungus. In addition, genetic factors such as lecithin expression of deficiency in the host cells may favor colonization by Candida spp [36].

The intimate soap keeps the acid and pH vulvovaginal Candida easily proliferates in this condition. However, in this study the reported use of this product, in part, prevented the onset of VVC. However, no investigation of the frequency of its use prevented the reliability of the findings Table 2 .

The use of intimate toilet soap, in the vulvar and vaginal introitus region not interfere with the physiological vaginal $\mathrm{pH}$ and, in some situations, can protect the flora of the vaginal opening, hel- ping to combat other infections that succumb to acid $\mathrm{pH}$. Vaginal $\mathrm{pH}$ is a result of the secretion of organic acids by vaginal epithelial cells and the production of acid by the Doderlein bacilli from glycogen [37].

The intimate soaps act on feminine hygiene and the acidic $\mathrm{pH}$ maintenance, vulva and vaginal opening [38]; during the menstrual cycle, particularly during menstruation, that $\mathrm{pH}$ changes. Other factors also temporarily change as intercourse, condom use and internal and external absorbent [37, 39].

The statistical dependence found between positive vaginal cultivate and previous use of antibiotics can be explained because the use of antibiotics may alter the vaginal flora, as it suppresses the lactobacillus and, therefore, can trigger the selective proliferation of micro-organisms. They were being inhibited. Thus, both can increase the colonization, the infection Candida spp [6, 10,40].

The lactobacillus act as guardians of female internal genitalia and, when fewer facilitate the occurrence of multiple infections [37]. These operate at three different levels against pathogens: compete with fungi, for nutrients; performing a process of co-aggregation by blocking epithelial receptors, preventing the adhesion thereof to the vaginal epithelium; and produce substances capable of inhibiting the germination of micelles [10].

The vaginal flora is rich in Lactobacilli producing hydrogen peroxide, which form lactic acid from glycogen, which makes the acidic vaginal $\mathrm{pH}$, hindering the proliferation of most pathogens.

Many factors influence the amount of Lactobacilli doderlein as systemic or topical use of antibiotics, stress, medications or diseases that reduce immunity, and the hyperestrogenism [9].

Thus, the vaginal microflora is one of the most important defense mechanisms, maintaining healthy vaginal environment and preventing the proliferation of foreign microorganisms at the same [40]. 
Stress is related to the release of hormones that alter various aspects of human physiology and can modulate the body's defenses, increasing susceptibility to infections or worsen the course of the same, due to decreased cellular immunity [41].

Nevertheless, the findings of this research contradict this statement about stress, taking to infer that the self-report of stressful situations may have been overestimated by women investigated. Moreover, the role of humoral immunity in protection against mucosal and systemic fungal infections remains controversial [10]. Authors state that the equilibrium of the vaginal ecosystem is maintained by complex interactions between the normal vaginal flora, the microbial metabolism products, the hormonal state and the immune response of the host [42]. Thus, cellular immunity appears to be the most important factor against immune microorganism proliferation in the vagina. It occurs an activation of cell-mediated immune response, and macrophages phagocytosis and destroys effectively, which keeps the concentration of Candida in subclinical levels [42].

Regarding the statistical dependence of Candida culture and menstrual cycle, there is no consensus, but the presence of regular menstrual cycles has been identified as an important risk factor for vaginal candidiasis, with the highest incidence of cases from the peak of estradiol [43].

The explanation for this fact is that during the menstrual cycle hormonal changes occur that interfere with substrate of different microorganisms. These variations and the presence of menstrual blood leading to vaginal $\mathrm{pH}$ changes [39].

\section{Conclusion}

The research revealed a high incidence of candidiasis, compared to existing data on the basis of literature consulted. Considering that most of the respondents had a low educational level, were sexually active and young adults, it is appropriate that further research be carried out to investigate aspects of Candida, and that there will be educational activities in order to prevent such infestation or your aggravation.

By the fact that this infection is considered a public health problem, it is important that professionals working in this area are kept up to date on the pathogenesis of VVC, for the proper management of this infection.

\section{References}

1. Jayatilake JAMS, Samaranayake LP. Experimental superficial candidiasis on tissue models. Mycoses. 2010; 53(4): 285-295. DOI: 10.1111/j.14390507.2010.01879.x

2. Playford EG, Marriott D, Nguyen Q, Chen S, Ellis D, Slavin M, Slavin M, et al. Candidemia in non neutropenic critically ill patients: risk factors for non-albicans Candida spp. Critical Care Medicine. 2008; 36(7): 2034-2039. DOI: 10.1097/ cCM.0b013e3181760f42

3. Pfaller MA, Diekema DA. Epidemiology of invasive candidiasis: A persistent public health problem. Clin Microbiol Rev. 2007; 20(1): 133-163. Pumed PMID: 17223626; Pumed PMCID: PMC1797637.

4. Galván B, Mariscal F. Epidemiología de la candidemia en UCl. Rev Iberoam Micol. 2006; 23(1): 12-15. DOI: 10.1016/S11301406(06)70005-5

5. Martins NV, Ribalta JCL. Patologia do trato genital inferior. 2nd ed. São Paulo: Roca; 2014.

6. Ziarrusta GB. Vulvovaginitis candidiásica. Rev. Iberoam Micol. 2002; 19: 22-24.

7. Correa PR, David PRS, Peres NP, Cunha KC, Almeida MTG. Caracterização fenotípica de leveduras isoladas da mucosa vaginal em mulheres adultas. Rev Bras Ginecol Obstet. 2009; 31(4): 177-181. DOI 10.1590/S0100-72032009000400004

8. Zimmermmann JB, Freitas CL, Perígolo LF, Campos PC, Mourão RPC, Bicalho LF. Avaliação do tratamento antifúngico oral e tópico-oral para a candidíase vulvovaginal. HU Revista. 2009; 35(3): 167-173. LILACS: 543907.

9. Sobel JD. Vulvovaginitis in health women. Compr Ther. 1999; 25(6/7): 335346. Pubmed PMID: 10470518.

10. Álvares CA, Svidzinski TIE, Consolaro MEL. Candidíase vulvovaginal: fatores predisponentes do hospedeiro e virulência das leveduras. J Bras Patol Med Lab. 2007; 43(5): 319-327. DOI: 10.1590/S1676-24442007000500004 
11. Ferrazza MHSH, Maluf MLF, Consolaro MEL, Shinobu CS, Svidzinski TIE, Batista MR. Caracterização de leveduras isoladas da vagina e sua associação com candidíase vulvovaginal em duas cidades do Sul do Brasil. Rev Bras Ginecol Obstet. 2005; 27(2): 58-63. DOI: 10.1590/S0100-72032005000200003

12. Spinillo A, Carratta L, Pizzoli G, Lombardi G, Cavanna C, Michelone $G$, et al. Recurrent vaginal candidiasis: results of a cohort study of sexual transmission and intestinal reservoir. J Repro Med. 1992; 37: 343-347. Pubmed PMID: 1593559.

13. Corsello S, Spinillo A, Osnengo G, Penna C, Guaschino S, Beltrame A, et al. An epidemiological survey of vulvovaginal candidiasis in Italy. Eur J Obstet Ginecol Reprod Biol. 2003; 110: 66-72. Pubmed PMID: 12932875.

14. Sebitlone MH. HIV and gynecological infections. Best Pract Res Clin Obstet Gynaecol. 2005; 19(2): 231-241. DOI: 10.1016/j. bpobgyn.2004.10.003

15. Rosa MI, Rumel D. Fatores associados a candidiase vulvovaginal: estudo exploratório. Rev Bras Ginecol Obstet. 2004; 26(1): 65-

70. DOI 10.1590/S0100-72032004000100010

16. Nardin ME. Prevalencia de la candidiasis vulvovaginal y su relación con algunos factores de riesgo. Rev Argent Microbiol. 2000.

17. Sobel JD. Vaginal infections in adult women. Med Clin North Am. 1990; 74(1): 1575-1602. Pubmed PMID: 2246954.

18. Lacaz CS, Porto E, Martins JEC, Heins-vaccari EM. Tratado de micologia médica. 9. ed. São Paulo: Sarvier; 2002.

19. Sidrim JJC, Rocha MFG. Micologia médica a luz de autores contemporâneos. 1. ed. Rio de Janeiro: Guanabara Koogan; 2004

20. Baldim IM, Pereira MA, Rufini LRA, Oliveira NMS, Fiorini JE. Teste de sensibilidade ao quefir de cepas de Candida sp. isoladas de vulvovaginites. Rev Cienc Farm Básica. 2012; 33(3): 379-383. ISSN 1808-4532.

21. Indicadores de Desenvolvimento Brasileiro. Brasília; 2013. Available from: <http: //www.febrasgo.org.br/site/wp-content/ uploads/2013/05/femina-v37n4-p229.pdf>

22. Borges ALV, Schor N. Início da vida sexual na adolescência e relações de gênero: um estudo transversal em São Paulo, Brasil 2002. Cadernos de saúde Pública. 2005; 21(2): 499-507. DOI: 10.1590/S0102-311X2005000200016

23. Zimmermmann JB, Nani $A C G$, Junqueira $C B$, lani $G C M$, Gomes G, Bahia S. Aspectos ginecológicos e obstétricos de pacientes atendidas nos serviços público e privado de saúde. Há diferenças? Rev Bras Ginecol Obstet. 2011; 33(12): 401-407. DOI: $10.1590 / S 0100-72032011001200005$

24. Morris M, Nicoll A, Simms I, Wilson J, Catchpole M. Bacterial vaginosis: a public health review. British Journal of Obstetrics and Gynaecology. 2001; 108(5): 439-450. DOI: 10.1111/j.14710528.2001.00124.x
25. Carvalho WR, Farias ES, Guerra JG. A idade da menarca está diminuindo? Rev Paul Pediatria. 2007; 25(1): 76-81. LILACS: 462329 .

26. Klug DP, Fonseca PHS. Analise da maturação feminina: um enfoque na idade de ocorrência da menarca. Rev da Educ Fís / UEM. 2006; 17(2): 139-147.

27. Castilho Sd, Pinheiro CD, Bento CA, Barro-Filho AZ, Cocetti M. Tendência secular da idade da menarca avaliada em relação ao índice de massa corporal. Arq Bras Endocrinol Metab. 2012; 56(3): 195-200. DOI: 10.1590/S0004-27302012000300008

28. Leone ET, Maia AG, Baltar PR. Mudanças na composição das famílias e impactos sobre a redução da pobreza no Brasil. Economia e Sociedade. 2010; 19(1): 59-77. DOI: 10.1590/S010406182010000100003

29. IBGE, Instituto Brasileiro de Geografia e Estatística. Nupcialidade e fecundidade. Dados do Censo 2010. Available from: http: //7a12.ibge.gov.br/vamos-conhecer-o-brasil/nosso-povo/ nupcialidade-e-fecundidade

30. Boing AF, d'Orsi $E$, Reibnitz $C$. Conceitos e ferramentas da epidemiologia - módulo3. Universidade Aberta do SUS - UFSC. Brazil; 2010.

31. De Lorenzi DRS, Saciloto B. Frequência da atividade sexual em mulheres menopausadas. Rev Assoc Med Bras. 2006; 52(4): 256-260. DOI: 0.1590/S0104-42302006000400027

32. Santos MD, Sala MG. Climaterio y menopausa. Parte II. La Sexualidad em el climatério. Sexol Soc. 1999; 5(3): 17-19.

33. Achakar JM, Fries BC. Candida infections of the genitourinary tract. Clinical Microbiology Reviews.2010; 23(2): 253-273. DOI: 10.1128/CMR.00076-09

34. Guzel $A B$, Ilkit $M$, Burgut $R$, Urunsak IF, Ozgunen FT. An evoluation of risk factors in pregnant women with Candida vaginits and the diagnostic value of simultaneous vaginal and retal sampling. Micopathologic. 2011; 172(1): 25-36. Pubmed PMID: 21293929.

35. Ribeiro AA, Oliveira DF, Sampaio MCN, Carneiro MAS, Tavares SBN, Souza NLA, et al. Agentes microbiológicos em exames citopatológicos: Estudo de prevalência. Rev Bras Anal Clin. 2007; 39(3): 179-81. LILACS: 501851.

36. Calderon L, Williams R, Martinez M, Clemons KV, Stevens DA. Genetic susceptibily to vaginal candidasis. Medical Mycology. 2003; 41(2): 143-147. Pubmed PMI 12964847.

37. Jármy-DiBella ZIK, Araujo MP, Martins KDF, Zucchi EVM, Girão MJBC, Sartori MGF. O uso de sabonetes íntimos femininos. Femina. 2009; 37(4): 229-234

38. Roy S, Caillouette JC, Roy T, Faden JS. Vaginal Ph is similar to follicle stimulating hormonal e for menopausa diagnosis. Am J Obstet Gynecol. 2004; 190(5): 1272-1277. Pumed PMID: 15167829 
39. Schwebke JR, Richey CM, Weiss HL. Correlation of behaviors with microbiological changes in vaginal flora. The Journal of Infectious Diseases. 1999; 180(5): 1632-1636. Pubmed PMID: 10515826

40. Linhares IM, Witkin SS, Miranda SD, Fonseca AM, Pinotti JA, Ledger WJ. Differentiation between women with vulvovaginal symptoms who are positive or negative for Candida species by culture. Infect Dis Obstet Gynecol. 2001; 9(4): 221-225. DOI: 10.1155/S1064744901000369

41. Amâncio DCO, Nunes MTCC, Cardoso MAG. Resposta imune humoral frente à situação de estresse. XIV Encontro Latino Americano de Iniciação Científica e X Encontro Latino Americano de Pós-Graduação - Universidade do Vale do Paraíba. Brazil; 2010.

42. Giraldo PC, Passos MRL, Bravo R, Varella RQ, Campos WNA, Amaral RL, Marussi E. O frequente desfio do entendimento e do manuseio da vaginose bacteriana. DST J bras Doenças Sex Transm. 2007; 19(2): 84-91. INSS: 0103-4065.

43. Holanda AAR, Fernandes ACS, Bezerra CM, Ferreira MAF, Holanda MRR, Holanda JCP, et al. Candidíase vulvovaginal: sintomatologia, fatores de risco e colonização anal concomitante. Rev Bras Ginecol Obstet. 2007; 29(1): 3-9. DOI: 10.1590/S010072032007000100002
Comment on this article:
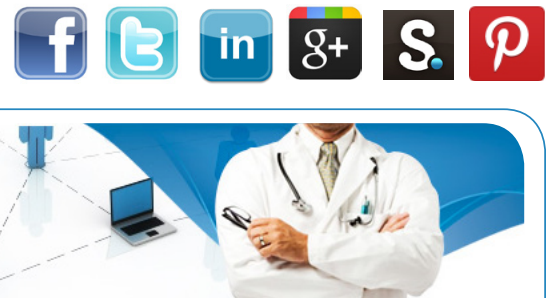

http://medicalia.org/

Where Doctors exchange clinical experiences, review their cases and share clinical knowledge. You can also access lots of medical publications for free. Join Now!

\section{Publish with iMedPub}

http://www.imed.pub

International Archives of Medicine is an open access journal publishing articles encompassing all aspects of medical science and clinical practice. IAM is considered a megajournal with independent sections on all areas of medicine. IAM is a really international journal with authors and board members from all around the world. The journal is widely indexed and classified Q1 in category Medicine. 